\title{
KSZTAŁCENIE FILOLOGICZNE A DYDAKTYZACJA PRZEKŁADU
}

\begin{abstract}
Zarys treści. Artykuł jest próbą określenia miejsca i roli, jaką zajmuje i odgrywa przekład w nauczaniu języka obcego na kierunkach filologicznych. Przedmiot rozważań stanowią również różnice w mechanizmach poznawczych istniejące pomiędzy umiejętnościami tłumaczeniowymi a umiejętnościami językowymi. W artykule poddano analizie istniejącą sytuację edukacyjną, a także założenia programowe ilustrujące tezy artykułu. W warstwie praktycznej artykuł oparty jest na dydaktycznym doświadczeniu autorki (czerpanym z nauczania przekładu w Katedrze Filologii Angielskiej UMK).
\end{abstract}

\section{Miejsce tłumaczenia w kształceniu uniwersyteckim}

Tł łumaczenie stanowi integralną część kształcenia na kierunkach filologicznych na wielu polskich uniwersytetach. Jest obowiązkową częścią programu praktycznej nauki języka, jednakże w ramach takiego programu uważane jest za kwestię problematyczną i wymagającą analizy (dla porównania negatywnych i pozytywnych aspektów takiego wykorzystania przekładu zob. Malmkjaer 1998).

Rosnące zapotrzebowanie na tłumaczy w nowej sytuacji zjednoczonej Europy stanowi ważki argument w dyskusji nad wykorzystaniem przekładu w ramach dydaktyki języka obcego. $Z$ drugiej jednak strony nie należy ignorować faktu, że nie wszyscy studenci kierunków filologicznych chcą być w przyszłości tłumaczami, a zatem dla nich przekład nie jest nadrzędnym celem nauki języka obcego. W trakcie zajęć z tłumaczenia pisemnego studenci często wyrażają zainteresowanie poszerzaniem słownictwa, a nie innymi aspektami przekładu (np. rolą kultury w przekładzie, typami tekstu etc.). W dydaktyce języka obcego przekład odbierany jest jako zachowanie 
adekwatności semantycznej (zdaniowej, frazowej) w danej sytuacji tłumaczeniowej. Ocena tłumaczeń dokonanych przez studentów wymaga spełnienia kilku podstawowych kryteriów, zgodnie z którymi przekład jest poprawny i może być uznany za dobry, gdy odpowiada kryteriom akceptacji przez odbiorcę docelowego (Kussmaul 1983; 1995) w odniesieniu do realizacji przyjętych celów komunikacyjnych w każdej sytuacji translacyjnej (takich jak: kontekst, sytuacja tekstowa, efekty stylistyczne). Ocena takiego przekładu różni się zatem w zależności od osoby oceniającej - studentów lub nauczyciela; prowadzi to niewątpliwie do pewnego subiektywizmu. Kompetencja w zakresie transferu semantycznego związana jest $\mathrm{z}$ umiejętnością identyfikowania dających się zweryfikować kryteriów oceny i ekwiwalencji. Można więc powtórzyć za Adab (1995), że jeżeli przyjmie się, iż przekład to czynność oparta na zdolnościach i zorientowana na cel, odwołująca się do uprzedniego doświadczenia poznawania dwóch kultur i języków, wtedy student musi być świadomy zakresu wymaganego doświadczenia, musi wiedzieć, w jaki sposób może zaradzić brakom w doświadczeniu, a także, przede wszystkim, jak może rozwijać umiejętności, które pozwolą mu na osiągnięcie celów.

Zdobycie umiejętności tłumaczeniowych pociąga za sobą pewną formę informacji zwrotnej wynikającej ze społecznych i kulturowych zjawisk funkcjonujących w środowisku i otoczeniu tłumacza. Wraz ze wzrostem i rozwojem wiedzy i doświadczenia u tłumacza, informacja pochodząca $\mathrm{z}$ jego środowiska asymilowana jest poprzez społeczną interakcję i ostatecznie tworzy część ogólnego bagażu wiedzy każdego tłumacza. Studenci, dla których przekład to ćwiczenie gramatyczne, nie są świadomi konieczności powiększania tego bagażu i poszerzania wiedzy. Należy zatem przyjać, że z im bardziej zróżnicowanymi sytuacjami zetknie się początkujący tłumacz, tym bardziej elastyczne stają się jego wzorce zachowań w sytuacjach translacyjnych i tym samym zwiększa się jego zdolność adaptacji (do nowych sytuacji).

Nastawienie studentów do tłumaczenia w trakcie realizacji zajęć zmienia się - zaczynają bowiem zdawać sobie sprawę, że przekład nie oznacza zamiany leksykalnych odpowiedników na te, które uważają za bardziej odpowiednie, ale jest to złożony proces przetwarzania informacji, wymagający wiedzy kulturowej i znajomości języka jako całego systemu, który powstaje i tworzy się na bazie doświadczenia i posiadanego zasobu wiedzy. 


\section{Różnica pomiędzy umiejętnościami tłumaczeniowymi a umiejętnościami językowymi}

Od strony psychologicznej proces przekładu przewyższa swoją złożonością cztery umiejętności językowe (czytanie, pisanie, słuchanie i mówienie). Proces ten opiera się na takich podstawach, jak: wiedza, zdolności poznawcze (np. pamięć, dostęp leksykalny, czyli identyfikacja słowa przechowywanego w pamięci), doświadczenie oraz świadomość potencjalnych problemów, które mogą się pojawić. Podstawy te nie są zbieżne z czynnikami ważnymi dla 'klasycznego' uczenia się języków obcych - mechanizmy poznawcze mają inny charakter i dlatego nie poddają się (subiektywnej) ocenie. W tym momencie nasze rozważania wchodzą w trudną dziedzinę roli (oraz zastosowania) bilingwizmu w tłumaczeniu; te aspekty nie staną się jednak przedmiotem naszej dyskusji z racji ograniczonego rozmiaru niniejszego artykułu. Pomimo elementarnej umiejętności porozumiewania się (por. Lörscher 1991) oraz innych kategoryzacji (takich jak np. model rozwojowy, por. Harris 1977; Harris, Sherwood 1978) bilingwizm nie może być podstawą ze względu na wspomniane powyżej czynniki poznawcze przy przetwarzaniu informacji.

W przypadku tłumaczy mamy do czynienia z ekspozycją znacznie szerszego zakresu domen funkcjonalnych i komunikacyjnych związanych z elementami w języku L1 i L2 niż u osób bilingwalnych (Groot de 1997; Shreve 1997), ponieważ osoba bilingwalna i tłumacz wydobywają różne bodźce z informacji wejściowej: osoby bilingwalne uzyskują informację relewantną językowo, natomiast tłumacze - relewantną dla danej sytuacji translacyjnej. Wyjaśnia to Shreve (1997), pisząc, że podstawa poznawcza profesjonalnego przekładu może być pochodną zdolności poznawczych wspólnych również dla osób bilingwalnych, natomiast należy zaznaczyć, że w tym procesie uczestniczą też inne struktury poznawcze. Specyficzne transformacje wiedzy na temat przekładu oraz sposobu tłumaczenia pojawiają się wtedy, kiedy jednostka zaczyna gromadzić doświadczenie danego rodzaju, np. doświadczenie tłumaczeniowe.

Niektóre powiązania reprezentacji mentalnych pochodzą z wcześniejszego doświadczenia tłumaczeniowego, które jest ipso facto niedostępne dla osób bilingwalnych, a zatem z aktywacji i rozwoju (wydobywania) zasobów pamięci długotrwałej w realizacji zadania komunikacyjnego. Powiązania międzyjęzykowe (szybkie, automatyczne, zachodzące pomiędzy reprezenta- 
cjami językowymi w językach L1 i L2) nie wymagają pośredniego kanału reprezentacji pojęciowych (Groot de 1997; Shreve 1997).

\section{Analiza sytuacji}

Kompetencja tłumaczeniowa stanowiła punkt wyjścia dla rozważań niemieckich badaczy, które miały swoje podłoże w badaniach empirycznych (np. Kussmaul 1995; Lörscher 1991; Wilss 1996). Badania te dotyczyły perspektywy rozwijania kompetencji tłumaczeniowej u przyszłych tłumaczy, co w sposób nieunikniony zorientowane było na kształcenie tłumaczy poprzez realizację modeli opartych na psychologii. Modele były wynikiem rozważań teoretycznych i, w dość szerokim zakresie, opierały się na empirii; stąd też można zauważyć znaczący udziału wielu badaczy przekładu w badaniach zorientowanych na kształcenie. Powyższe zaangażowanie jest eksplikacją przyjętej perspektywy patrzenia na przekład zdydaktyzowany jako na kształcenie tłumaczy w celu podkreślenia potrzeby opracowania nowego modelu nauczania. Za Mackenzie (1998) można powtórzyć, iż celem dydaktyki języka obcego w kształceniu tłumaczy jest przekazanie im narzędzi koniecznych w pracy tłumacza-profesjonalisty.

Ogólnie rzecz ujmując, tłumaczenie kompetentne to przekazywanie wiedzy ponad językowymi i kulturowymi granicami, opierające się i wykorzystujące doświadczenie, umotywowaną chęć dalszego rozwoju oraz umiejętność współpracy z przedstawicielami innych kultur. Kształcenie tłumaczy koncentruje się zatem na języku wykorzystywanym jako instrument w sytuacjach zróżnicowanych komunikacyjnie i kulturowo, stanowi jednak tylko jedno z całego szeregu narzędzi potrzebnych do umiejętnego przekazywania treści zawartych w języku źródłowym, umiejętności stosowania strategii i technik służących dokonaniu dobrego przekładu. Rola procesów poznawczych jest zatem niezwykle istotna, ponieważ implikuje istnienie podstawowych zdolności umysłowych, dzięki którym tłumacz zdaje sobie sprawę $\mathrm{z}$ powstających problemów oraz może przetwarzać, gromadzić i akumulować informacje oraz wiedzę pochodzącą z tekstu.

Pogląd ten odzwierciedlony jest również w dychotomii Kiraly’ego (2000), który rozróżnia kompetencję tłumaczeniową (translatorską, translation competence) i kompetencję tłumacza (translator competence). Pierwsza określa zdolność tworzenia adekwatnych tekstów w języku docelowym, a druga - zdolność do wykorzystywania narzędzi i informacji w celu stworzenia komunikatywnych tekstów akceptowanych i uznawanych w danej społecz- 
ności za dobre przekłady. Przejście od kompetencji tłumaczeniowej do kompetencji indywidualnej tłumacza można zatem traktować jako obraz krzywej rosnącej w kierunku specjalizacji, wiedzy eksperckiej, zdolności do zbierania i przechowywania potrzebnych informacji oraz stosowania ich w nowych, nieznanych dotąd sytuacjach.

W naszych rozważaniach należałoby podkreślić jeszcze jeden aspekt, a mianowicie znaczenie wiedzy teoretycznej, ponieważ jej opanowanie i stosowanie wydatnie przyczynia się do wzrostu samoświadomości tłumacza, jego profesjonalizmu oraz powiększa jego ekspercką wiedzę. Połączenie teorii i praktyki w kształceniu tłumacza jest zatem - jak pisze Kaiser-Cooke (2000) - nie tylko zbieżne, ale też konieczne; teoria zatem to teoria stosowana. Wyniki działań praktycznych mogą więc prowadzić do powstania teorii wywodzących się z empirycznie uwarunkowanych oczekiwań i uogólnień. Takie aspekty przekładu jak językowo wyrażone czynniki kulturowe (np. normy; por. Toury 1995), wpływ tłumacza na tekst i jego interpretację, typy tekstów, świadomość istnienia związanych z tłumaczeniem procesów, takich jak rozwiązywanie problemów i podejmowanie decyzji czy też strategii tłumaczeniowych tworzą integralną część kształcenia, czyli podstaw teoretycznych, na jakich mogą opierać się studenci.

\section{Założenia i cele programowe}

Założenia leżące u podstaw dydaktyki języka obcego na studiach filologicznych przewidują realizowanie takich elementów, jak: rozwijanie umiejętności werbalnych (przez, na przykład, rewerbalizację, parafrazę), rozwijanie zasobu leksykalnego, rozwijanie umiejętności stylistycznych, rozwijanie zrozumienia funkcjonowania języka (języków), konsolidacja struktur języka obcego oraz monitorowanie i rozwijanie rozumienia języka obcego.

Przy rozważaniach nad kształceniem tłumaczy nasuwa się pytanie: kto ma być przedmiotem kształcenia? Celem takiego kształcenia jest wyszkolenie i przygotowanie tłumaczy profesjonalnych, jednakże to założenie jest realne wyłącznie na gruncie rozważań teoretycznych, ponieważ stopniowy, ewolucyjny charakter rozwoju koniecznych kompetencji wymaga odpowiedniego czasu. Wspomniane powyżej wyniki badań empirycznych nie dają podstawy do określenia, na czym mógłby opierać się rozwój kompetencji tłumaczeniowej u studentów, co mogłoby zaowocować negatywnymi konsekwencjami; mianowicie w obecnych tendencjach kształcenia tłumaczy nie widać nacisku położonego na różnice istniejące pomiędzy eksperta- 
mi a tymi, którzy ekspertami nie są (czyli studentami); w zamian za to mamy do czynienia z terminami 'kształcenie ekspertów'. Priorytetem staje się nauczanie technik i strategii jako czynników decydujących o powodzeniu tłumacza (zgodnie z postulatami stawianymi przez takich badaczy, jak: Lörscher 1991; Kussmaul 1995 lub Mackenzie 1998). Podkreśla się również znaczenie wiedzy (językowej, tekstowej, kulturowej). Prowadzi to do traktowania potencjalnego absolwenta specjalizacji tłumaczeniowej jako eksperta przekładu, który ma jednak pewne niedostatki wiedzy lub brakuje mu doświadczenia. Tym samym nie posiada fundamentu, na którym mógłby się oprzeć. A zatem, pomimo wysiłków ze strony nauczyciela oraz badaczy, 'produkt' końcowy jest nadal produktem profesjonalnym w połowie, a nie w całości. Założenia teoretyczne towarzyszące tworzeniu obrazu potencjalnego programu tłumaczeniowego obejmują następujące czynniki:

1) celem kształcenia jest kształcenie profesjonalistów (ekspertów), natomiast praktyka pokazuje, że studenci po ukończeniu kursu tłumaczeniowego (lub specjalizacji) są nadal jedynie adeptami zawodu;

2) czas trwania kształcenia powinien wynosić przynajmniej dwa lata;

3) kształcenie powinno obejmować zagadnienia związane z użyciem języków specjalistycznych;

4) program powinien również uwzględniać studia kulturowe;

5) studenci koncentrować się też powinni na tekście (analiza tekstu, konwencje, typy tekstów);

6) język ojczysty studentów (często pomijany w kształceniu tłumaczy ze względu na przekonanie, że student doskonali go przez całe życie) jest przedmiotem intensywnego treningu (a także związane z nim studia kulturowe, analiza tekstu oraz języki specjalistyczne).

Tłumacze podlegają procesowi ciągłego i nieustannego kształcenia. Ich zdolność twórcza odbierana jest i poddawana ocenie w odniesieniu do jakości wyników ich pracy. Znaczenie rozwoju tłumacza polega zatem na zbudowaniu podstaw, które mogą być wykorzystane do stworzenia dobrego przekładu.

\section{Tłumaczenie na język ojczysty}

Tłumaczenie z języka ojczystego wymaga aktywacji znajomości języka obcego wraz z towarzyszącymi tej czynności innymi aspektami, relewantnymi dla określonego kontekstu w określonej sytuacji translacyjnej. Tłumaczenie na język ojczysty ma natomiast służyć sprawdzeniu rozumienia informacji zawartej w komunikacie w języku obcym. 
Odpowiednie użycie języka polskiego wśród studentów pozostaje nadal kwestią dość kontrowersyjną, co znajduje swój wyraz w problemach z formułowaniem poprawnych zdań i zwrotów po polsku. Język ojczysty traktowany jest jako narzędzie komunikacji w grupie rówieśniczej, a warunek jego poprawności nie stanowi warunku priorytetowego. Problemy związane z właściwym użyciem języka polskiego wyraźnie wynikają z braku kontaktu z językiem ( $w$ formie pisania i czytania w tym języku). Studenci kierunków filologicznych nie uznają znajomości języka ojczystego w swojej przyszłej karierze zawodowej jako czynnika koniecznego, co w konkretnym przypadku studentów filologii angielskiej może dziwić. Takie nastawienie wynika głównie z przeświadczenia, że posiadają już biegłą znajomość języka, wynikającą z samego faktu bycia rodzimym użytkownikiem tego języka. Nie dostrzegają konieczności kształtowania i doskonalenia języka ojczystego w takim samym stopniu, jak języka obcego. Uważają ponadto, że tłumaczenie na język ojczysty jest łatwiejsze i dlatego też nie podchodzą do tej czynności z odpowiednią motywacją. Traktują swoją rzekomą biegłość w języku ojczystym jako rzecz zupełnie naturalną (i przyjmują ją za pewnik).

\section{Uwagi końcowe}

$\mathrm{Na}$ kierunkach filologicznych tłumaczenie jest stosowane jako jedna z metod poznawania i doskonalenia języka obcego. W tym kontekście celem studenta-tłumacza jest poinformowanie odbiorcy (nauczyciela) o swojej znajomości języka obcego, natomiast cel tłumacza w tłumaczeniu profesjonalnym polega na poinformowaniu odbiorcy (czytelnika) o treści zawartej w języku oryginału (Klaudy 1995). W kształceniu tłumaczy aspekty teoretyczne muszą być powiązane z praktyką tłumaczeniową, z obserwacją empiryczną dokonań (np. na podstawie używanych w psycholingwistycznie ukierunkowanych badaniach Protokołów Głośnego Myślenia) oraz rozważaniami dotyczącymi czynności, które można wykonać w danym kontekście i z daną intencją komunikacyjną. Na kierunkach filologicznych tłumaczenie wykorzystywane jest jako środek do testowania (a także do oceny) kompetencji językowej w języku ojczystym i języku obcym. Powstaje zatem pytanie: czy tłumaczy należy kształcić tylko w instytucjach specjalistycznych szkolących tłumaczy, czy też elementy profesjonalnego specjalistycznego programu tłumaczeniowego powinny być ujęte w ramach szerszego programu kształcenia językowego. Nacisk kładzie się na edukację, a tłumaczenie 
jest tylko jednym z elementów, które mają przyczynić się do aktywizacji (i rozwijania) kompetencji językowej. Tłumaczenie jest więc jednym $z$ etapów na drodze do osiągnięcia zaawansowanej znajomości języka na kierunkach filologicznych, natomiast nadrzędnym celem specjalistycznych instytucji kształcących tłumaczy (najczęściej w ramach studiów podyplomowych) jest zapewnienie studentom kształcenia profesjonalnego (zawodowego). Musi jednak zostać zachowana równowaga pomiędzy tymi dwiema perspektywami, a zatem należałoby dokonać gruntownej analizy programów.

Włączenie przedmiotu zwanego 'tłumaczeniem' do programu praktycznej nauki języka prowadzi do niejasności i wątpliwości związanych z tym przedmiotem: z jednej strony ma on służyć przygotowaniu studentów do egzaminu z praktycznej znajomości języka, natomiast część tegoż poświęcona tłumaczeniu polega na tłumaczeniu zdań (najczęściej dwóch lub trzech), które nie mogą być traktowane jako tekst, ponieważ zdania wyjęte z kontekstu nie pozwalają studentom na uświadomienie sobie znaczenia kontekstu dla tłumaczenia w ogóle. Ponadto realizacja celu, czyli zdanie egzaminu, uniemożliwia wprowadzenie programu zawierającego podstawowe założenia teorii przekładoznawczych czy znajomości technik i strategii tłumaczeniowych, w naturalny sposób narzucając zajęciom $z$ tłumaczenia niejako sztuczny charakter. Można oczywiście zgodzić się z faktem, że dydaktyka przekładu realizowana w trybie dwusemestralnym jest prawie niemożliwa. Należałoby zatem postawić postulat, aby odizolować tłumaczenie od programu praktycznej nauki języka obcego i realizować go jako osobny przedmiot specjalizacyjny.

Na konieczność takiej przebudowy programu studiów na kierunkach neofilologicznych, by uwzględniały kompetencje translatoryczne, zwrócił już uwagę Antoni Dębski (2002), a Lech Zieliński (w druku) pokazał w swoich rozważaniach, jak można translatorykę zakotwiczyć na kierunkach neofilologicznych po dostosowaniu ich do wprowadzanego w Europie modelu bolońskiego.

\section{Literatura}

Adab, Beverly J., 1996, „Training students to see how the pieces of the jigsaw fit together", [w:] B. Lewandowska-Tomaszczyk, M. Thelen (eds.), Translation and Meaning, Maastricht: Universitaire Pers Maastricht, part 3, s. $28-292$. 
Bowen, David, 1994, „Teaching and learning styles”, [w:] Cay Dollerup, Annette Lindegaard (eds.), Teaching Translation and Interpreting 2. Insights, Aims, Visions, Amsterdam-Philadelphia: John Benjamins, s. 175-181.

Danks, Joseph H. et al. (eds.), 1997, Cognitive Processes in Translation and Interpreting, Thousand Oaks-London-New Delhi: Sage.

Dębski, Antonii, 2002, „Po co studiować dzisiaj filologię obcą? Słowo o curriculum studiów neofilologicznych i kompetencjach ich absolwentów", [w:] Język a komunikacja 4, t. 2: Język trzeciego tysiąclecia II. Polszczyzna a języki obce: przykład i dydaktyka, red. Władysław Chłopicki, Kraków, s. 257-262.

Dollerup, Cay, Loddegaard, Annette, 1992, Teaching Translation and Interpreting. Training, Talent and Experience, Amsterdam-Philadelphia: John Benjamins.

Dollerup, Cay, Lindegaard, Annette, 1994, Teaching Translation and Interpreting 2. Insights, Aims, Visions, Amsterdam-Philadelphia: John Benjamins.

Dollerup, Cay, 1994, „Systematic feedback in teaching translation”, [w:] Cay Dollerup, Annette Lindegaard (eds.), Teaching Translation and Interpreting 2. Insights, Aims, Visions, Amsterdam-Philadelphia: John Benjamins, s. 121-132.

Dollerup, Cay, Appel, Vibeke, 1995, Teaching Translation and Interpreting 3. New Horizons, Amsterdam-Philadelphia: John Benjamins.

Dollerup, Cay, 1995, „The emergence of the teaching of translation”, [w:] Cay Dollerup, Vibeke Appel (eds.), Teaching Translation and Interpreting 3. New Horizons, Amsterdam-Philadelphia: John Benjamins, s. 19-30.

Gile, Daniel, 1994, „The process-oriented approach in translation training”, [w:] Cay Dollerup, Annette Lindegaard (eds.), Teaching Translation and Interpreting 2. Insights, Aims, Visions, Amsterdam-Philadelphia: John Benjamins, s. 107-112.

Groot, Annette M. B. de, 1997, „The Cognitive Study of Translation and Interpretation: Three Approaches", [w:] Joseph H. Danks et al. (eds.), Cognitive Processes in Translation and Interpreting, Thousand Oaks-London-New Delhi: Sage, s. 25-56.

Harris, Brian and Bianca Sherwood, 1978, „Translation as an innate skill”, [w:] D. Gerver and H. W. Sinaiko (eds.), Language and Communication, New York: Gardner, s. 155-170.

Kaiser-Cooke, Michele, 2000, „Theory in practice: translation as trans-disciplinary action", [w:] Mira Kadric, Klaus Kaindl, Franz Pöchhacker (eds.), Translationswissenschaft, Tubingen: Stauffenburg Verlag, s. 67-79. 
Kadric, Mira, Kaindl, Klaus, Pöchhacker Franz (eds.), 2000, Translationswissenschaft, Tübingen: Stauffenburg Verlag.

Kiraly, Don, 2000, A Social Constructivist Approach to Translator Education. Empowerment from Theory to Practice, Manchester: St. Jerome Publishing.

Klaudy, Kinga, 1995, „Quality assessment in school vs professional translation", [w:] Cay Dollerup, Vibeke Appel (eds.), Teaching Translation and Interpreting 3. New Horizons, Amsterdam-Philadelphia: John Benjamins, s. 197-204.

Kussmaul, Paul, 1995, Training the Translator, Amsterdam-Philadelphia: John Benjamins.

Lewandowska-Tomaszczyk, Barbara, Thelen, Marcel (eds.), 1996, Translation and Meaning, part 3, Maastricht: Universitaire Pers Maastricht.

Lörscher, Wolfgang, 1991, Translation Performance, Translation Process, and Translation Strategies, Tübingen: Gunter Narr Verlag.

Mackenzie, Rosemary, 1998, „The Place of Language Teaching in a Quality Oriented Translators' Training Programme”, [w:] K. Malmkjær (ed.), Translation and Language Teaching, Manchester: St. Jerome Publishing, s. $15-19$.

Maia, Belinda, 1996, „The role of translation theory in the teaching of general and non-literary translation", [w:] B. Lewandowska-Tomaszczyk, M. Thelen (eds.), Translation and Meaning, part 3, Maastricht: Universitaire Pers Maastricht, s. 164-173.

Malmkjær, Kirsten, (ed.), 1998, Translation and Language Teaching, Manchester: St. Jerome Publishing.

Pym, Anthony, 1992, „Translation error analysis and the interface with language teaching", [w:] Cay Dollerup, Annette Loddegaard (eds.), Teaching Translation and Interpreting: Training, Talent and Experience, Amsterdam-Philadelphia: John Benjamins, s. 278-288.

Reiss, Katharina, Vermeer, Hans J., 1984, Grundlegung einer allgemeinen Translationstheorie, Tübingen: Niemeyer.

Sainz, Maria Julia, 1995, „Awareness and responsibility: our students as partners", [w:] Cay Dollerup, Vibeke Appel (eds.), Teaching Translation and Interpreting 3. New Horizons, Amsterdam-Philadelphia: John Benjamins, s. 137-144.

Shreve, Gregory M., 1997, „Cognition and the Evolution of Translation Competence", [w:] Joseph H. Danks et al. (eds.), Cognitive Processes in Translation and Interpreting, Thousand Oaks-London-New Delhi: Sage, s. $120-137$. 
Snell-Hornby, Mary, 1992, „The professional translator of tomorrow: language specialist or all-round expert?", [w:] Cay Dollerup, Annette Loddegaard (eds.), Teaching Translation and Interpreting: Training, Talent and Experience, Amsterdam-Philadelphia: John Benjamins, s. 9-22.

Toury, Gideon, 1995, Descriptive Translation Studies and Beyond, Amsterdam-Philadelphia: John Benjamins.

Ulrych, Margherita, 1995, „Real-world criteria in translation pedagogy”, [w:] Cay Dollerup, Vibeke Appel (eds.), Teaching Translation and Interpreting 3. New Horizons, Amsterdam-Philadelphia: John Benjamins, s. 251-259. Wilss, Wolfram, 1996, Knowledge and Skills in Translator Behavior, Amsterdam-Philadelphia: John Benjamins.

Witte, Heidrun, 1995, „Contrastive culture learning in translator training”, [w:] Cay Dollerup, Vibeke Appel (eds.), Teaching Translation and Interpreting 3. New Horizons, Amsterdam-Philadelphia: John Benjamins, s. $73-79$.

Zieliński, Lech (w druku), „Nauczanie przekładu (tekstów fachowych) na kierunkach neofilologicznych. Stan obecny, perspektywy rozwoju", w serii: Język a komunikacja 8, Kraków.

\section{Language teaching vis-à-vis didactic approach to translation} (summary)

Challenges that translation faces in the globalised modern world, with an increasingly growing demand for translators, instigate the need for the discussion on its didactics-related aspects. The article attempts at the definition of the place and role occupied by translation in the training and foreign language teaching at university (philology) departments. Differences in cognitive processing existing between translation skills and language skills constitute one of the foci of our deliberations. The present educational situation as well as syllabus outlines, underlying this article, were also subject to analysis.

As far as the pragmatic perspective is concerned, the article relies on didactic experiences of the author (stemming from translation teaching experience at the English Department of the Nicholas Copernicus University in Toruń). 